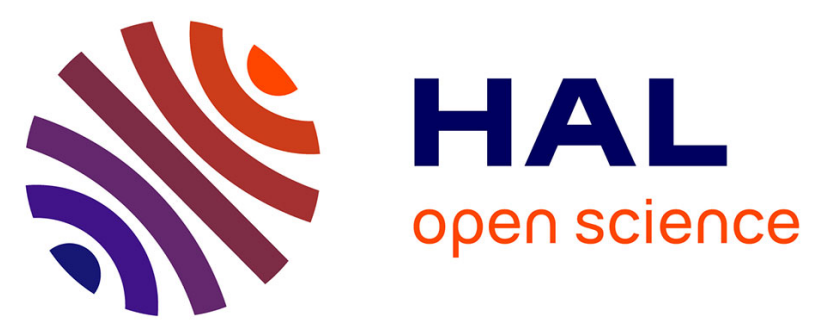

\title{
Non-Invasive on-site Raman study of blue-decorated early soft-paste porcelain: the use of Arsenic-rich (European) cobalt ores-Comparison with huafalang Chinese porcelains
}

\author{
Philippe Colomban, Ting-An Lu, Véronique Milande
}

\section{To cite this version:}

Philippe Colomban, Ting-An Lu, Véronique Milande. Non-Invasive on-site Raman study of bluedecorated early soft-paste porcelain: the use of Arsenic-rich (European) cobalt ores-Comparison with huafalang Chinese porcelains. Journal of the European Ceramic Society, 2018, 38 (15), pp.5228-5233. 10.1016/j.jeurceramsoc.2018.07.001 . hal-01900407

\section{HAL Id: hal-01900407 https://hal.sorbonne-universite.fr/hal-01900407}

Submitted on 22 Oct 2018

HAL is a multi-disciplinary open access archive for the deposit and dissemination of scientific research documents, whether they are published or not. The documents may come from teaching and research institutions in France or abroad, or from public or private research centers.
L'archive ouverte pluridisciplinaire HAL, est destinée au dépôt et à la diffusion de documents scientifiques de niveau recherche, publiés ou non, émanant des établissements d'enseignement et de recherche français ou étrangers, des laboratoires publics ou privés. 
Non-Invasive on-site Raman study of blue-decorated early soft-paste porcelain: the use of Arsenic-rich (European) cobalt ores - Comparison with huafalang Chinese porcelains Philippe Colomban, ${ }^{1}$ Ting-An Lu ${ }^{1}$, Véronique Milande ${ }^{2}$

${ }^{1}$ Sorbonne Universités, UPMC Univ. Paris 06, MONARIS UMR8233, CNRS, 4 Place Jussieu, 75005 Paris, France

${ }^{2}$ Département du Patrimoine et des Collections de la Cité de la Céramique, 92310 Sèvres, France

corresponding author:philippe.colomban@upmc.fr Tel+33144272785; fax $+33144273021$

\section{Abstract}

Both European and Asian historical records report that Jesuits were at the origin of enamelling technology transfers from France (and Italy) to Asia during the $17^{\text {th }}$ century. A mobile Raman set-up equipped with a high magnification (x200) microscope objective with long working distance is used to identify the use of European (arsenic-rich) cobalt in $17^{\text {th }}$ and $18^{\text {th }}$ century porcelains: twenty soft-paste porcelains from Rouen (L. Poterat' Factory), SaintCloud, Paris (Pavie', Hébert', Chicanneau', and Bellevaux' factories), Lille, Mennecy, and Vincennes factories, of which almost all were produced before 1750, belonging to the Cité de la Céramique Collection (formerly Musée national de Céramique, Sèvres), have been analysed in order to get a more representative view of the type of cobalt ore used. A large proportion of blue decors exhibit signs of lead arsenate, even for productions after $\sim 1750$, which proves the wilful interest given to arsenic phases in magnifying blue hues. Different lead arsenate signatures are observed, one assigned to the product of reaction of As-rich cobalt ore with lead-based glaze and another characteristic of added arsenic. At least two groups of glaze are identified: a lead-rich one and a mixed lead-alkali glaze. Porcelains made during the second half of the $18^{\text {th }}$ century exhibit the very strong As-O modes characteristic of the voluntary addition of a lead-arsenate forming compound. Comparisons are made with Qing Chinese productions exhibiting similar Raman signatures and expected to have benefited from transfers of technologies.

\section{Keywords}


B: Impurities; B: Spectroscopies; C: colour; D: Glass; arsenic; porcelain

Graphical Abstract

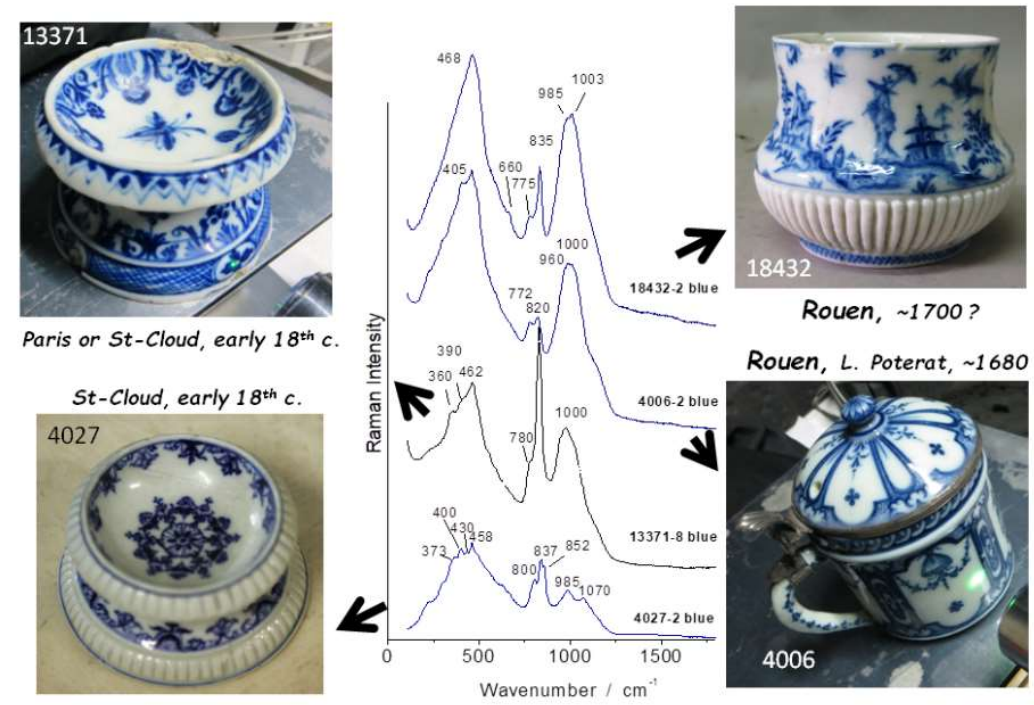




\section{Introduction}

Porcelains made from kaolin, feldspar, and sand are a Chinese innovation, a notable example of the many advancements in ceramic technology that occurred in China many centuries before reaching Europe [1]. However, some European technologies did inspire some Asian productions: for instance, the cloisonné enamel technique [2] is assumed to have spread from the Byzantine Empire to China by means of the Silk Road Trade. Important Jesuit Missions were established at the end of $16^{\text {th }}$ century in Japan and during the $17^{\text {th }}$ century in China, and, according to both Chinese and European historical records, facilitated access to experts in glass and enamelling technologies, as well as the importation of enamelled artefacts and glaze precursors to the Qing Court [3-6]. At that time, the decor of Asian porcelains didn't produce 'realistic' (overglaze) paintings, as opposed to the well delimited coloured areas made of opaque enamels which allowed for 'realistic' pictures as in European easel paintings. Indeed, Chinese pottery is decorated with pale enamels that looks like watercolours [7-9]. Blue decors of Asian porcelains are directly painted on the porous green body and then covered with a glaze precursor layer and subsequently fired at the high temperature required to form porcelains $\left(\sim 1300-1450^{\circ} \mathrm{C}\right)[1,9-11]$. Consequently, the porcelain glaze melts at the (top) firing temperature of the body and its composition contains a significant level of alumina and a rather limited amount of flux $\left(\mathrm{K}_{2} \mathrm{O}, \mathrm{Na}_{2} \mathrm{O}\right.$ and $\mathrm{CaO}$ [12-16]. In Europe, this technique is called 'Grand Feu' firing [14-18]. The colour palette of 'Grand Feu' porcelain is limited $[17,18]$ and coloured enamels must be added on the already fired artefact and heated again using the 'Moufle' or the 'Petit Feu' techniques. Leadbased enamels are fired at Moufle $\left(\sim 1050^{\circ} \mathrm{C}\right)$ or 'Petit Feu' $\left(800\right.$ to $\left.600^{\circ} \mathrm{C}\right)$ temperatures [1520]. The 'Petit Feu' technique was first used on soft-paste porcelains (i.e. porcelain made without kaolin, see further down) because the limited thermal stability of the paste and is linked to the glazing techniques developed for fritwares and faience/majolica $[16,19]$. 'Petit $\mathrm{Feu}^{\prime}$ technique allows for the preparation of realistic paintings visually similar to oil paintings as obtained by Limoges enamels (on metal) [20-22]. These complex painted decors were made using lead-rich mixtures deposed on already fired and glazed objects. The origin of the 'Petit Feu' technique can be traced to Ottoman (Iznik) and Persian (minai ware) potters that develop complex decors obtained by successive firings of lead-based glazes [23-25] on fritware bodies: the body it-self was made by soldering a sand-rich mixture with lead-based 
"cement" $[15,19,23,24]$. Soft-paste porcelains belong to the same type of pottery as fritware: due to the absence of kaolin, a mixture of sand, chalk/marl, and glue is shaped and fired. Hard-paste porcelain made with kaolin and feldspar accept a rather large shift in firing temperatures (up to $\sim 100^{\circ} \mathrm{C}$ ) [26], thanks to the prior formation of a network of acicular mullite crystals in the body during the firing. The mullite network retains the molten part of the body by capillarity $[9,12,13,27,28]$, which while cooling, gives it its amorphous phase and hence translucence : on the contrary soft-paste porcelains requires a well-defined temperature; a small downward-shift of the firing temperature leads to porous bodies while a small upward-shift leads to a complete deformation or even a flattening of the object (Fig. S1, Supplementary Materials). The decor should be put on the already fired (non-porous) body in decreasing temperature increments of around $100 / 200^{\circ} \mathrm{C}$ if it requires the superposition of many colours $[17,20]$.

Archaeometric studies of early produced soft-paste porcelains are rather limited. In the 1980s Kingery et al. [9,28] conducted optical and Scanning Electron Microscopy and fluorescence analyses on polished Saint-Cloud, Chantilly and Sèvres shards and measured the elemental composition of the body and of some glazes of soft- and hard-paste porcelains. Preliminary Raman study was conducted by Colomban and Treppoz [26]. The first comprehensive Raman microscopy study published in French in 2004 by Colomban et al. presented a selection of 17 artefacts of Saint-Cloud, Chantilly, Mennecy, Vincennes and Sèvres Factories; all item belonging to the Sèvres Musée National de Céramique (MNC) Collection [29]. The study performed at the laboratory with a fixed high-resolution spectrometer was focused on the identification of the crystalline phases in the body and in the glaze (opacifiers and pigments). Recently Sceaux Factory soft-paste artefacts (18 porcelains and a few faiences) were analysed on site by Raman microspectroscopy using the mobile set-up used in this work [30]. Reference European porcelain bodies and glazes have also been analysed in the same way [17,31-33]. Elemental and raw material compositions of soft-paste porcelain produced at Sèvres National Factory, the continuation of the Royal factory founded at Vincennes by Louis XV, King of France, were also published by d'Albis $[15,18]$ and much earlier by Brongniart [16]. Bodies and glaze compositions were also given by Deck [19], Munier [34], Bertran [20] and de Plinval de Guillebon [35,36]. Recently, 
Maggetti and d'Albis analysed in detail the microstructure of a 1781 soft-paste plate from Sèvres Royal Factory using SEM-EDS [37].

We present here an on-site Raman study at the Cité de la Céramique with a mobile Raman set-up of 20 soft-paste porcelain objects with blue décor. The artefacts were selected among the oldest ones in the collection (Table 1 and Supplementary Materials), in particular three pots attributed to the Rouen Factory: one assigned to Louis Poterat (circa 1680) and considered as the oldest European porcelain to be preserved [36-38], if we except very rare Medici porcelain objects made, one century before at Florence, with a very specific paste, intermediate between soft and hard paste ones [9,16,32]. Among a series of early European porcelains, we select three artefacts from the Saint-Cloud Factory (two of them made ca. 1700 or before) and 6 items from the famous early $18^{\text {th }}$ century Paris Factories (Edouard Hébert, Dominique \& Pierre Chicaneau, Antoine Pavie and Bellevaux) [35,36,38]. Soft-paste porcelains from Lille, Mennecy, Vincennes and Sèvres and some early hard-paste porcelains from Strasbourg (Hannong Factory) and Meissen (Saxony) complete the corpus. Comparison will be made with data collected on two very representative Chinese potteries: a huafalang Imperial bowl (Kangxi reign, ca. 1715-1722) and a Yixing tea pot stoneware $\left(2^{\text {nd }}\right.$ half of the $18^{\text {th }}$ century) selected from previous studies of $17^{\text {th }}-18^{\text {th }}$ centuries Chinese porcelains and stonewares [7].

French soft paste production was described by Hellot (reported in ref. [14]) and Brongniart [16] as a mixing of a frit and a very plastic illite calcareous clay from Argenteuil. The frit is made of soda ash, sea salt, potassium nitrate, silica and lime or gypsum, milled together and then fired (firing temperature, $\sim 1100^{\circ} \mathrm{C}$ ). The resulting matter is crushed, milled and mixed with the Argenteuil clay (8-10\% wt) and then shaped, trimmed or turned, and bisque fired before the application of a lead-based glaze. More details can be found in d'Albis et al. papers $[15,18,37]$. The characteristic crystalline phase of soft-paste porcelain is wollastonite $\left(\mathrm{CaSiO}_{3}\right)$, but cristobalite $\left(\mathrm{SiO}_{2}\right)$, and trydimite $\left(\mathrm{SiO}_{2}\right)$ crystals form in smaller amount from the (partial) dissolution of quartz grains $[14,15,26,29]$.

Erzgebirge mining (Saxony) was the principal source of cobalt ores in Europe at that times and consisted in a mixture of skutterite $\left(\mathrm{CoAs}_{3}\right)$, smaltite $\left((\mathrm{Co}, \mathrm{Ni}, \mathrm{Fe}) \mathrm{As} s_{2}\right)$, safflorite $\left(\mathrm{CoAs}_{2}\right)$, cobaltite (CoAsS) and arsenate erythrite $\left(\mathrm{CO}_{3}\left(\mathrm{AsO}_{4}\right)_{2} \cdot 8 \mathrm{H}_{2} \mathrm{O}\right)[39,40]$. Ores are more or less grilled that eliminates some arsenic and even incorporated in molten glass to form smalt 
[40]. A source from the Pyrenees mountains is also reported by Magetti and d'Albis for artefacts made at the end of the $18^{\text {th }}$ century [37]. The mixing of these arsenic-rich ores with a lead-rich glaze led to the precipitation of lead arsenate, e.g. as follow:

$$
\mathrm{CoAs}_{3}+\left[\mathrm{Pb}_{3} \mathrm{O}_{4}+n \mathrm{niO}_{2}\right]_{\text {liq. }}=>3 \mathrm{PbAsO}_{4}+\left[\mathrm{Co}^{2+} \mathrm{nSiO}_{2}\right]_{\text {glass }}
$$

Indeed, the glaze may contain some other fluxing ions $\left(\mathrm{Ca}^{2+}, \mathrm{Na}^{+}\right.$and $\left.\mathrm{K}^{+}\right)$that could give more complex phases and compositions [41]. Because of the high toxicity of (soluble or volatile) arsenic derivatives, the number of studies on these compounds, especially from a vibrational point of view, is very limited, while studies of natural compounds are less scarce $[42,43]$. It is well known that the Raman intensity first depends on the bond polarisability, i.e. from the number of electrons involved in the bond. Due to its position in the Periodic Table $(Z=33)$, the As-O bond polarisability is large and its symmetric stretching mode strong [44]. Consequently, lead arsenates are easily detected by Raman scattering, with an intense feature at ca. $820 \mathrm{~cm}^{-1}[7,8,41-44]$. We will thus focus our attention on this wavenumber range in order to get a representative view of the presence of lead-based arsenate in association with the blue decors of ancient porcelains.

\section{Experimental}

\subsection{Technique}

The mobile Raman set-up associates a HE532 Horiba Jobin-Yvon spectrometer, fibre optics connected to a remote Superhead(R) equipped with a high-magnification LWD ( 13 $\mathrm{mm}$ ) microscope objective and a $532 \mathrm{~nm}$ Ventus Quantum laser. For a recorded spectrum of higher quality, a x200 Mitutoyo microscope is preferred (laser spot waist $<0.4 \mu \mathrm{m}$, close to the diffraction limit [8]) regardless of the larger time required to adjust the focus $[45,46]$. The exceptional quality of this optic limits the extension of the focus volume along the $Z$ direction to about $2 \mu \mathrm{m}$, regardless of the enlargement of the laser spot within the matter due to the optical index of the glaze. The thickness of the coloured film and the size of pigment's grains/crystals can be very small (a few $\mu \mathrm{m}$ ), and it is necessary that the laser spot intercepts at the best the coloured matter. Due to the high sensitivity of the HE532 spectrometer, the recording time, including 3 to 100 accumulations to avoid cosmic ray spikes, ranges between 1 and $60 \mathrm{sec}$. The illumination power at the sample's position is 
selected between $\sim 20 \mathrm{~mW}$ (body and colourless glaze analysis) and 1 to $10 \mathrm{~mW}$ (more or less coloured areas).

\subsection{Artefacts}

Figs 1 and 2 show most of the studied artefacts. All items are listed in Table 1 and photographs of all artefacts, including their Factory' mark, dimension and origin (and the collected spectra) are given as Supplementary Materials. Assignments reported in Table 1 are those indicated in the MNC records. They will be further discussed. Complementary historical information, including mark assignments, can be found in refs $[36,38]$.

\section{Historical context}

As said in the introduction, the studied corpus consists of a very representative set of early French porcelains with a blue décor. Exceptionally rare, they were first produced in the Rouen Factory by Louis Poterat, a faience producer that obtained in 1673 the first Royal Privilege from King Louis XIV of France in order to make porcelain. It's a very limited production which stopped in 1696 and thus only consisted of a very few number of items. The second group belongs to the Saint-Cloud Factory production, a factory founded by Pierre $1^{\text {st }}$ Chicaneau, and which started to produce porcelain in 1693 under the patronage of Monsieur, the King' brother (Fig. 1). The latter factory was visited by E. Von Tchirnhaus [35] before he started making hard-paste porcelain in Dresden and Meissen [26]. The production stopped in 1766. Note that some of the selected artefacts come from a Paris subsidiary of the Saint-Cloud Factory (la Ville l'Evêque) managed by Pierre $2^{\text {nd }}$ Chicaneau and Marie Moreau. Pierre Pélissier, in relation with the Saint-Cloud Factory, helped Antoine Pavie to produce soft-paste porcelains in Paris after 1703: three artefacts are assigned to this production. A Chicaneau's daughter married a member of the Hébert family and some porcelain produced by the Hébert Factory were also selected. Other artefacts were produced at Lille (Factory founded in 1711), Mennecy (founded in 1737) and Vincennes (founded circa 1738-1740, Fig. 2). The famous Chemist René Antoine Ferchault de Réaumur, with the help of Letters sent by Père d'Entrecolles describing the production of hard-paste porcelain at Jingdezhen (China)[47], worked with two masters of the Pavie' Factory (F. Barbin and P. Pélissé) and tried to make scientifically translucent 'porcelain' [35]. Artefacts with a specific JB mark are assigned to Jean-Baptiste Bellevaux's Factory (see Supplementary Materials). J.-B. Bellevaux also first worked at the Saint-Cloud Factory $[35,36]$. The selected 
artefacts are thus important pieces of the history of porcelain. Note that because of the very poor plasticity of green porcelain pastes, the size of these first items is small. The better plasticity of hard-paste green body makes possible the preparation of bigger artefacts. Assignment of the origin of some artefacts remains disputed and thus a better knowledge of the technology used to produce these objects is welcome.

Treatment of cobalt ores by roasting incompletely eliminates arsenic, and consequently blue enamels from the $17^{\text {th }}$ century still contain a significant level of arsenic $[39,40]$. Complementary treatments with sulphuric or hydrochloric acid increased the purity of cobalt. The decrease of the content of residual arsenic in blue glass during the $17^{\text {th }}$ century is well established for Trade glass beads $[48,49]$ and for Limoges enamels $[21,22,50]$. Recent on-site Raman analysis of Chinese porcelain masterpieces [7] and combined elemental and Raman analysis of similar shards $[8,44]$ have demonstrated that many blue and green glazes of $18^{\text {th }}$ century Chinese porcelains exhibit specific Raman signatures at $\mathrm{ca} .830 \mathrm{~cm}^{-1}$ and a relatively high level of arsenic is detected in association to cobalt $[8,44,51]$. On the other hand, this signature was not observed on blue-decorated porcelains from the Ming Dynasty thanks to the use of arsenic-free Asian cobalt ores (rich in manganese and iron) [52-59].

\section{Results}

\subsection{Raman signature of crystalline phases}

Figs 3 and 4 show characteristic spectra recorded with the focused laser spot intercepting blue or blue-green areas, at the best as possible. Spectra recorded on the body, on white glaze, and on other coloured areas are given in Supplementary Materials. We will first consider the narrow peaks characteristic of crystalline phases dispersed within the glaze.

The peak observed at $\sim 462 \mathrm{~cm}^{-1}$ in many spectra is the strongest one of $\alpha$ quartz signature ( $\mathrm{SiO}_{4}$ bending mode). However, incompletely dissolved grains of quartz are commonly detected by Raman scattering $[10,17,26,29,30]$ in porcelain bodies and glazes. A more or less strong peak is observed at $815 \mathrm{~cm}^{-1}$ (Table 1) for a first series of blue (or green) regions (artefacts \# 6638, 8102, 13371, 24780, 25330, 26296 and 26502). This peak is attributed to lead arsenate. In the past, some papers have attributed similar Raman features at this wavenumber to olivine $\mathrm{CoSiO}_{4}$, a phase exhibiting a doublet at $\sim 815-820 \mathrm{~cm}^{-1}$ [60]. However, the higher polarizability of the As-O bond will make the As-O stretching mode covers the Co- 
$\mathrm{O}$ one, even if the number of As-O bonds is inferior to that of Co-O ones. The location of the peak shifts at $820 \mathrm{~cm}^{-1}$ in artefacts number 4006, 6638, 8800, 24780, 13371 and at ca. 830 (as in glass beads [49]) or $835 \mathrm{~cm}^{-1}$ for the last group of artefacts $(4027,13369,13371$, 17063,18432 and 18433). When the intensity of the peak is small, the superimposition of Co-O and As-O components could explain the shift, but not when strong band intensity is observed: like in artefacts \#4027, 8800, 13369 and 17063 (Fig. 4). A $870 \mathrm{~cm}^{-1}$ peak is observed in blue-green 17063 décor and is assigned to a chromate (this point will be discussed further down). The $815 \mathrm{~cm}^{-1}$ more or less strong peak is mainly observed in the Vincennes (or Sèvres) Factory production (1748 to 1764), while a $820 \mathrm{~cm}^{-1}$ peak is observed both in some mid-18 ${ }^{\text {th }}$ century Vincennes/Sèvres porcelains and in some early artefacts assigned to Poterat (4006), Saint-Cloud (8800) and Chicaneau-Moreau (13371) Factories. The last group dated to the end of the $17^{\text {th }}$ century to the beginning of the $18^{\text {th }}$ century (Rouen 18432; Saint-Cloud 4027; Chicaneau-Moreau 13371; Pavie 13369 \& 18433; and Lille 17063) exhibits peaks at 830 or $835 \mathrm{~cm}^{-1}$. The 13371 artefact, assigned to the Chicaneau-Moreau Paris workshop, exhibits the three types of signatures.

The above-mentioned peaks were not observed in some pots: those assigned to the SaintCloud Factory (4135), Hébert Factory (9827), in a bowl from the Pavie workshop (13385), in pots from Lille (13361), in an unassigned artefact (13354), a Mennecy (13281) one and in a coffee cup from the Hébert Factory (13345). No arsenate signatures were observed for blue decorated hard-paste porcelains (2274, Meissen; 13675 and 13399, Hannong-

Strasbourg/Frankenthal) according the use of lead-free glaze, but an $815-823 \mathrm{~cm}^{-1}$ doublet was recorded for a multi-coloured hard paste from Strasbourg (13674) because the use of lead-based overglaze.

As a preliminary conclusion, three different signatures potentially attributed to arsenate-rich phases are thus observed. One group corresponds mainly to Saint-Cloud and its associated artefacts and to some Rouen productions. The second group corresponds to later productions. We will discuss the relationship with the glaze signature in the next paragraph. Narrow doublets at 635 and $967 \mathrm{~cm}^{-1}$ characteristics of (beta) pseudo-wollastonite, a phase typical of soft-paste glaze [29,30], are observed in all glazes except in those of hard paste porcelains and of the Poterat MNC4006 pot. Pseudo wollastonite requires a temperature of $1050-1100^{\circ} \mathrm{C}$ or more to form in calcium-rich glass [61]. The Raman signature of 
clinopyroxene phases with rather similar compositions ((Mg, $\left.\mathrm{Fe}, \mathrm{Ca}) \mathrm{SiO}_{3}\right)\left(665-1007 \mathrm{~cm}^{-1}\right.$ doublet [62]) is observed in some glazes (18432, 8800, 13371, 17063, 13361 and 13281). Note that these artefacts belong to the older group. This could indicate the use of a magnesium-rich raw material.

\subsection{Raman signature of amorphous phases}

The amorphous network of silicates is made of partially connected tetrahedron in which $\mathrm{Na}^{+}$, $\mathrm{K}^{+}, \mathrm{Ca}^{2+}, \mathrm{Pb}^{2+}$ flux ions and $\mathrm{Al}^{3+}$ ions are distributed in the sites delimited by the $\mathrm{SiO}_{4}$ network. The Raman signature of an amorphous silicate consists in two broad band at ca. 450-500 and 950-1050 $\mathrm{cm}^{-1}$ arising from the bending and stretching modes of $\mathrm{SiO}_{4}$ tetrahedrons [60-64]. Because the stretching mode of an isolated regular (Td symmetry) tetrahedron has $A_{1}$ symmetry (e.g. a single peak) and because the Raman intensity of asymmetric stretching modes is order of magnitude lower than the totally symmetric mode, the different components of the ca $950-1050 \mathrm{~cm}^{-1}$ band can be associated to the different $A_{1}$ peaks characteristics of each types of tetrahedron (isolated, connected by 1, 2, 3 or 4 oxygen atoms) forming the silicate network [63-67]: the Raman spectrum is thus the fingerprint of the silicate network. The symmetric and asymmetric bending modes having $E$ and $F$ character respectively, the number of components is more important, 10 and 15 respectively, and it is not possible to individualise them! But it has been demonstrated experimentally $[63,68]$, and theoretically [69Vanessa], that the area ratio of the bending band with respect to that of the stretching band, both for crystalline and amorphous silicates, is a measure of the polymerisation degree of the $\mathrm{SiO}_{4}$ network and hence is directly linked to the melting temperature. Much information can thus be extracted from the Raman spectrum.

The position and shape of the $\mathrm{SiO}_{4}$ stretching band gives information on the glaze type $[63,64]$. Three types of glaze signatures can be recognized: i) a first one with a $\mathrm{SiO}_{4}$ stretching band peaking at $\sim 980-1005 \mathrm{~cm}^{-1}$, characteristic of lead-rich composition [23,64]; ii) a second one characterized by a band with two sub-maxima at about 980 and $1030-1040 \mathrm{~cm}^{-1}$, and characteristic of a mixed lead-alkali glaze [64] as used for Iznik and Kutahya glazed fritware $[24,70]$ for instance, and iii) the alkali glaze fired at high temperature with hard-paste porcelain body peaking at $\sim 1060-1070 \mathrm{~cm}^{-1}[17,26,64]$. A mixed lead-alkali glaze is observed for artefacts assigned to the second half of the $18^{\text {th }}$ century and these glazes are free of 
clinopyroxene. Note that yellow and green glazes belong to the LR group because the formation/conservation of Naples yellow pyrochlore requires a lead-rich glassy matrix [71].

\section{Discussion}

As proposed in previous Raman studies $[26,29,30]$, wollastonite peaks are characteristic of soft-paste bodies and glazes and very efficient to discriminate between soft- and hard-paste porcelains, even with a mobile Raman set-up which performances remain inferior to that of an advanced laboratory instrument. The very characteristic huge fluorescence of Sanson's Factory production should be noted. Measurements on other artefacts from the same Factory already pointed out a huge fluorescence [72]. The observation of additional diopside (clinopyroxene) peaks appears characteristic of some early made soft-paste porcelains. As previously observed for Saint-Cloud's soft-pastes [9,29], at least two compositions of glaze have been used. And except for artefacts \#4027 (Saint-Cloud, 1700, sun mark, see Supplementary Materials) and 13281 (Mennecy, >1731), the lead-rich composition corresponds well to the beginning of the production. The mixed AL glaze corresponds to artefacts produced during the second part of the $18^{\text {th }}$ century (Table 1, artefacts 6638 and after). This puts in questions the dating of these two 4027 and 13281 objects. The estimation of the processing temperature of the glazes from their $\mathrm{SiO}_{4}$ bending-to-stretching area ratio, i.e. the Polymerization Index as defined in refs [63] and [68] led to ca. $1000-1100^{\circ} \mathrm{C}$ (Ip 1-2) and $700-800^{\circ} \mathrm{C}(\mathrm{Ip} \sim 0.3-0.8)$ is consistent with previous measurements [29] in accordance with a Moufle and Petit Feu firing, respectively.

The observation of a very strong As-O stretching mode in artefacts attributed to the second half of the $18^{\text {th }}$ century is in accordance with the microstructure reported by Magetti and d'Albis for a 1781 Sèvres plate: lead arsenate forms large globules (1-5 $\mu \mathrm{m}$ diameters). The good focusing the laser spot $\left(\sim 0.5 \times 0.5 \times 2 \mu \mathrm{m}^{3}\right)$ on a globule explain the huge intensity of the As-O mode. In 1781 Sèvres plate Maggetti and d'Albis identify the highest concentration of cobalt in the glassy phase in between the globules, which is consistent with the use of two precursors: one arsenate rich and the second cobalt-containing smalt/ore. The much lower intensity of As-O stretching mode measured in older artefacts confirms the use of different precursors. The shift of the As-O mode position indicates some variations in composition and/or structure. Potassium is detected by Magetti and d'Albis in the arsenate globules. 
Potassium was also identified in $16^{\text {th }}$ Spanish majolica [73]. However in these majolica shards, the arsenate does not form globules and is associated with the cobalt. Calcium-lead $\left((\mathrm{Ca}, \mathrm{Pb})_{3}\left(\mathrm{AsO}_{2}\right)_{2}\right)$ and more complex phases $\left(\mathrm{NaKPb}_{8}\left(\mathrm{AsO}_{4}\right)_{6}\right)$ have been identified and attributed to the use of arsenic-rich zaffre [74-76].

As visible on Fig. 1, the vivid blue colours of first produced soft-paste porcelains require a relatively high concentration of cobalt (>0.5-1 wt\%, locally). The depositing (painting) of cobalt ore powder directly on the body, fired or not, appears more reasonable that the use of zaffre (cobalt already dissolved a glass matrix). Examination of polished sections is needed to further the discussion. Identification of chromate in 17063 (Lille) blue-green spots indicates the use of a chromium-rich pigment denoting the use of raw heterogeneous cobalt ores.

Comparisons with spectra recorded on blue and green enamels of Qing porcelains and stonewares objects (Fig. 5 and refs $[7,8]$ ) show very similar signatures belonging to the $A L$ group (mixed alkaline-lead glaze). As for soft-paste porcelains, the intensity of the arsenate phase is rather small in older artefacts and maximal for those produced in the second part of the $18^{\text {th }}$ century. This is consistent with the initial formation of lead arsenate by reaction with the arsenic coming from the cobalt source in older artefacts. For the second group of artefacts, a deliberate addition of arsenate in order to optimize the colour is probable and explains the stronger intensity of the As-O stretching mode.

The observation of different types of glaze for the artefacts attributed to the Rouen production questions the attribution to a single workshop or demonstrates an intense period of innovation with the search for different technologies. The same question can be raised for the 4027 salt container with the Saint-Cloud 'sun' mark.

\section{Conclusion}

On-site Raman analysis appears very efficient to recognize soft-paste porcelain and to detect lead arsenate in the glaze. The use of high magnification objectives allows for the study of coloured areas very precisely and the recording of high quality spectra. The main advantage of the technique is the study of series of precious artefacts with good pedigrees in a perfectly non-invasive way. The variety of As-O vibrational signatures and the possibility to 
have superimposition with that of olivine $\mathrm{CO}_{2} \mathrm{SiO}_{4}$ hinders a precise identification.

Furthermore, due to the high toxicity of arsenic, the availability of vibrational data on well characterized arsenic-based phases remains very limited. Combined Raman, SEM-EDX and (micro)diffraction on polished sections of porcelain shards exhibiting similar Raman signatures is needed to go deeper in the identification of the arsenate phases and establishing a link with characteristic microstructures related to the ancient procedures used by the potters. We see in this work the advantages and the limits of non-invasive study of ceramic objects.

\section{Acknowledgments}

The authors kindly thank Mrs L. Tilliard, Curator, Head of Collection Department for her help and support. French-China Cai Yuanpei 36685RB cooperative program and HORIBA Scientific Jobin-Yvon Company are kindly acknowledged for partial support. This work has been made in the framework of the CNRS-Palace Museum of Beijing LIA (Laboratoire international associé) production (La circulation des objets émaillés entre la France et la Chine (milieu XVII - milieu XIXe siècle): Interactions technologiques, culturelles et diplomatiques). 


\section{References}

1. N. Wood, Chinese Glaze: Their Origins, Chemistry, and Recreation, University of Pennsylvania Press, Philadelphia, 1999.

2. B. Kirmizi, Ph. Colomban, B. Quette, On-site Analysis of Chinese Cloisonné enamels from $15^{\text {th }}$ to $19^{\text {th }}$ century, J. Raman Spectrosc. 41[7] (2010) 780-790.

3. C.F. Shih, Evidence of East-West exchange in the eighteenth century: the establishment of painted enamel art at the Qing Court in the reign of Emperor Kangxi, Natl. Palace Mus. Res. Q. 24[3] (2007) 45-94.

4. F. Lili, La céramique chinoise, China Intercontinental Press, Beijing, 2011.

5. B. Zhao, G. Wang, I. Biron, Ph. Colomban, L. Hilaire-Pérez, La circulation des techniques de l'émail entre la France et la Chine du XVIIème au XIXème siècle, Le Cnrs en Chine Bulletin 21

$21-25$.

http://www.cnrs.fr/derci/IMG/pdf/cnrsenchine_21_fr_final_pour_le_site_cnrs.pdf

6. X.D. Xu, Europe-China-Europe: The Transmission of the Craft of Painted Enamel in the Seventeenth and Eighteenth Centuries, Goods from the East, 1600-1800 Trading Eurasia, Maxine Berg ed., Houndmills, Basingstoke, Hampshire: Palgrave Macmillan, 2015, pp. 92106.

7. Ph. Colomban, Y. Zhang, B. Zhao, Non-invasive Raman analyses of huafalang and related porcelain wares. Searching for evidence for innovative pigment technologies, Ceram. Int. 43[15] (2017) 12079-12088.

8. Ph. Colomban, F. Ambrosi, A.-T. Ngo, T.-A. Lu, X.-L. Feng, S. Chen, C.-L. Choi, Comparative analysis of wucai Chinese porcelains using mobile and fixed Raman microspectrometers, Ceram. Int. 43[16] (2017) 14244-14256.

9. W.D. Kingery, Ed., Ancient Technology to Modern Science, Ceramic and Civilization Vol. I (1984), Columbus, The American Ceramic Society Press.

10. N.Q. Liem, Ph. Colomban, G. Sagon, H.X. Tinh, T.B. Hoanh, Microstructure, Composition and Processing of the $15^{\text {th }}$ century Vietnamese Porcelains and Celadons, J. Cult. Herit. 4[3] (2003) 187-197.

11. Ph. Colomban, G. Sagon, L.Q. Huy, N.Q. Liem, L. Mazerolles, Vietnamese (15 ${ }^{\text {th }}$ century) blue-and-white, tam thai and "luster" porcelains/stoneware: glaze composition and decoration techniques, Archaeometry 46[1] (2004) 125-136.

12. W.M. Carty, U. Senapati, Porcelain - Raw materials, processing, phase evolution, and mechanical behavior, J. Am. Cer. Soc. 81[1] (1998) 3-20.

13. Y. Iqbal, W.E. Lee, Microstructural evolution in triaxial porcelain, J. Am. Cer. Soc. 83[12] (2000) 3121-3127. 
14. A. d'Albis, Procédés de fabrication de la porcelaine tendre de Vincennes d'après les livres de Hellot, Faenza LXIX[3-4] 1983, 202-216.

15. A. d'Albis, Steps in the Manufacture of the soft-paste porcelain of Vincennes, According to the book of Hellot, in pp257-272 Ceramic and Civilization I : Acient Technology to modern Science, Ed. W. Kingery, The American Ceramic Society, Colombus, 1985.

16. A. Brongniart, Traité des Arts Céramiques, 2 Vol. Paris 1854.

17. Ph. Colomban, G. Sagon, X. Faurel, Differentiation of antique ceramics from the Raman spectra of their coloured glazes and paintings, J. Raman Spectrosc. 32[5] (2001) 351-360.

18. A. d'Albis, Traité de la Porcelaine de Sèvres, Editions Faton, Dijon, 2003.

19. Th. Deck, La Faïence, Maison Quantin, Paris, 1887.

20. Bertan H. Nouveau Manuel Complet de la Peinture sur Verre, sur Porcelaine et sur Email, Mulo L, Libraire-Editeur. Encyclopédie-Roret: Paris, 1913.

21. Ph. Colomban, L. Arberet, B. Kirmizi, On-site analysis of $17^{\text {th }}-18^{\text {th }}$ centuries Limoges enamels. Arsenic and the technological relationship between enamelled Limoges and Chinese wares, Ceram. Int. 43[13] (2017) 10158-10165.

22. B. Kirmizi, Ph. Colomban, M. Blanc, On-site Analysis of Limoges enamels from $16^{\text {th }}$ to $19^{\text {th }}$ centuries, J. Raman Spectrosc. 41[10] (2010) 1240-1247.

23. G. Simsek, A.D. Geckinli, An assessment study of tiles from Topkapi Palace Museum with energy-dispersive X-ray and Raman spectrometers, J. Raman Spectrosc. 43[7] 2012, 917-927.

24. Ph. Colomban, V. Milande, L. Le Bihan, On-site Raman analysis of Iznik pottery glazes and pigments, J. Raman Spectrosc. 35[7] 2004, 527-535.

25. G. Simsek, Ph. Colomban, V. Milande, Tentative differentiation between Iznik tiles and copies with Raman spectroscopy using both laboratory and portable instruments, J. Raman Spectrosc. 41[5] 2010, 529-536.

26. Ph. Colomban, F. Treppoz, Identification and Differentiation of Ancient and Modern European Porcelains by Raman Macro- and Microspectroscopy, J. Raman Spectrosc. 32[2] (2001) 93-102.

27. Ph. Sciau, L. Noe, Ph. Colomban, Metal nanoparticles in contemporary potters' master pieces: Lustre and red "pigeon blood" pottery: Models to understand the ancient technology, Ceram. Int. 42[14] (2016) 15349-15357.

28. W.D. Kingery, E. Lense, Eds, High Technology Ceramics - Past, Present and Future. The Nature of Innovation and Change in Ceramic Technology, Vol. III, Ceramic and civilization Series, Columbus, The American Ceramic Society Press (1986).

29. Ph. Colomban, I. Robert, C. Roche, G. Sagon, V. Milande, Identification des porcelaines "tendres" du $18^{\text {ème }}$ siècle par spectroscopie Raman: Saint-Cloud, Chantilly, Mennecy et Vincennes/Sèvres, Revue d'Archéométrie 28 (2004) 153-167. 
30. D. Mancini, C. Dupont-Logié, Ph. Colomban, On-site identification of Sceaux porcelain and faience using a portable Raman instrument, Ceram. Int. 42[13] (2016) 14918-14927.

31. Ph. Colomban, V. Milande, H. Lucas, On-site Raman Analysis of Medici Porcelain, J. Raman Spectrosc. 35 [1] (2004) 68-72.

32. P. Ricciardi, Ph. Colomban, V. Milande, Non-destructive Raman characterization of Capodimonte and Buen Retiro porcelain, J. Raman Spectrosc. 39[8] (2008) 1113-1119.

33. H.G.M. Edwards, Ph. Colomban, B. Bowden, J. Raman Spectrosc. 35[8-9] 2004, 656-661.

34. P. Munier, Technologie des Faïences, Gauthiers-Villars, Paris, 1957.

35. R. de Plinval de Guillebon, Faïence et Porcelaine de Paris, XVIII-XIXe siècles, Editions Faton, Dijon, 1995.

36. R. de Plinval de Guillebon, L'Eveil de la porcelaine à Paris, Revue de la Société des Amis du Musée National de Céramique, 55-68, 2005, http://www.amisdesevres.com/wpcontent/uploads/2011/01/revue 19 55-68.pdf

37. M. Maggetti, A. d'Albis, Phase and compositional analysis of a Sèvres soft paste porcelain plate from 1781, with a review of early porcelain techniques, Eur. J. Mineral 29[3] (2017) 347-367.

38. A. Faÿ-Hallé, C. Lahaussois, La Porcelaine Française au XVIIIe siècle, Histoire, motifs et marques, Les Essentiels du Patrimoine, Massin, Paris, 2011

39. Ph. Colomban, Eur. J. Mineral. 25[5] (2013) 863-879.

40. M. Chevet, A. Chevalier, Eléments de Chimie d'après le Bon L.-J. Thénard, Traité élémentaire de Chimie, Chimie générale, Bibliothèque Populaire, 1833, Paris.

41. B. Manoun, M. Azdouz, M. Azrour, R. Essehli, S. Benmokhtar, L. El Ammari, A. Ezzahi, A. Ider, P. Lazor, Synthesis, Rietveld refinements and Raman spectroscopic studies of tricationic lacunar apatites $\mathrm{Na}_{1-\mathrm{x}} \mathrm{K}_{\mathrm{x}} \mathrm{Pb}_{4}\left(\mathrm{AsO}_{4}\right)_{3}(0<\mathrm{x}<1)$, J. Mol. Struct. 986[1-3] (2011) 1-9.

42. A. Culka, H. Kindlova, P. Drahota, J. Jehlicka, Raman spectroscopic indentification of arsenate minerals in situ at outcrops with handled $(532 \mathrm{~nm}, 785 \mathrm{~nm})$ instruments, Spectrochim. Acta Part A 154 (2016) 193-199.

43. J.T. Loprogge, L.V. Duong, M. Weier, W.N. Martens, Non-destructive identification of Arsenic and Cobalt minerals from Cobalt City, Ontario, Canada: Arsenolite, Erythrite, and Spherocobaltite on Pararammelsbergite, Appl. Spectrosc. 60[11] (2006) 1293-1296.

44. J. Van Pevenage, D. Lauwers, D. Herremans, E. Verhaeven,B. Vekemans, W. De Clercq, L. Vincze, L. Moens, P. Vandenabeele, A Combined Spectroscopic Study on Chinese Porcelain Containing Ruan-Cai Colours, Anal. Methods 6[2] (2014) 387-394.

45. Ph. Colomban, The on-site/remote Raman analysis with portable instruments - A review of drawbacks and success in Cultural Heritage studies and other associated fields, J. Raman Spectrosc. 43[11] (2012) 1529-1535.

46. Ph. Colomban, J. Raman Spectrosc. 49 (2018), in press 
47. Père d'Entrecolle's letters from Ching-te-chen in 1712 and 1722, translated in R. Tichane, Ching-te-Chen, New York State Institute for Glaze Research, Painted Post, New York, 1983.

48. R.G.V. Hancock, J. McKechnie, S. Aufreiter, K. Karklins, M. Kapches, M. Sempowski, J.F. Moreau, I. Kenyon, Non-destructive analysis of European cobalt blue glass trade beads, J. Radioanal. \& Nucl. Chem. 244[3] (2000) 567-573.

49. F. Koleini, I. Pikirayi, Ph. Colomban, Revisiting Baranda: a multi-analytical approach in the classification of sixteenth/seventeenth century glass beads from northern Zimbabwe, Antiquity 91[357] (2017) 751-765.

50. M. Blanc, I. Biron, Ph. Colomban, Emaux Peints de Limoges XVe-XVIIIe siècles, Les Arts Décoratifs, Paris, 2011.

51. R. Giannini, I.C. Freestone, A.J. Shortland, European Cobalt Sources Identification in the Production of Chinese Famille Rose Porcelain, J. Archaeolog. Sci. 80 (2017) 27-36.

52. D. de Waal, J. Raman Spectrosc. 35[8-9] (2004) 646-649.

53. L.D. Kock, D. de Waal, J. Raman Spectrosc. 38[11] (2007) 1480-1487.

54. E. Widjaja, G. H. Lim, Q. Lim, A. Bin Mashadi, M. Garland, J. Raman Spectrosc. 42[3] (2011) 377-382.

55. T. Wang, T. Zhu, M. Brunet, C. Deshayes, Ph. Sciau, J. Raman Spectrosc. 48[2] (2017) 267270.

56. M.O. Figueiredo, T.P. Silva, J.P. Veiga, A XANES study of cobalt speciation state in blueand-white glazes from $16^{\text {th }}$ to $17^{\text {th }}$ century Chinese porcelains, J. Electr. Spectrosc. \& Rel. Phenom. 185 (2012) 97-102.

57. M.I. Dias, M.I. Prudêncio, M.A. Pinto de Matos, A.L. Rodrigues, Tracing the origin of blue and white Chinese Porcelain ordered for the Portugese market during the Ming dynasty using INAA, J. Archaeolog. Sci. 40 (2013) 3046-3057.

58. T. Zhu, X. Ding, C.M. Kusimba, Z. Feng, Using laser ablation inductively coupled plasma mass spectroscopy (LA-ICP-MS) to determine the provenance of the cobalt pigment of qinghua porcelain from Jingdezhen in Yuan Dynasty of China (1271-1368 AD), Ceram. Int. $41[8]$ (2015) 9878-9884.

59. F. Du, B.R. Su, Further study of sources of the imported cobalt-blue pigment used on Jingdezhen porcelain from late 13 to early 15 centuries, Sci. China Series E - Techn. Sci. 51[3] (2008) 249-259.

60. T. Mouri, M. Enami, Raman spectroscopic study of olivine-group mineral, J. Mineralog. \& Petrolog. Sci., 103 (2008) 100-104.

61. Phase Equilibria Diagram Books, The American Ceramic Society, 2003, Westerville.

62. P. Ricciardi, Ph. Colomban, A. Tournié, M. Macchiarola, N. Ayed, A non-invasive study of Roman Age mosaic glass tesserae by means of Raman spectroscopy, J. Arch. Sci. 36 (2009) 2551-2559. 
63. Ph. Colomban, Polymerisation Degree and Raman Identification of Ancient Glasses used for Jewellery, Ceramics Enamels and Mosaics, J. Non-Crystalline Solids 323[1-3] (2003) 180187.

64. Ph. Colomban, A. Tournié, L. Bellot-Gurlet, Raman Identification of glassy silicates used in ceramic, glass and jewellry: a tentative differentiation guide, J. Raman Spectrosc. 37[8] (2006) 841-852.

65. Ph. Colomban, Pottery, Glass and Enamelled Artefacts: How to Extract Information on their Manufacture Technology, Origin and Age? Chapter 8, pp 245-267, in Analytical Archaeometry, H. Howell \& P. Vandenabeele Eds, Royal Society of Chemistry, Cambridge, 2012.

66. Ph. Colomban, Non-destructive Raman analysis of ancient glasses and glazes, ch. 4.2, in Modern Methods for Analysing Archaeological and Historical Glass, First Edition, K. Janssens Ed, John Wiley \& Sons Ltd, London (2012) p 275-300.

67. Ph. Colomban, L.C. Prinsloo, Optical Spectroscopy of Silicates and Glasses, Spectroscopic Properties of Inorganic and Organometallic Compounds, J. Yarwood, R. Douthwaite, S. B. Duckett Eds, RSC Publishing, The Royal Society of Chemistry, pp128-149, Cambridge 2009.

68. Ph. Colomban, A. Slodczyk, Raman intensity: An important tool to study the structure and phase transitions of amorphous/crystalline materials , Optical Materials, 31[12] (2009) 17591763.

69. V. Labet, Ph. Colomban, Vibrational properties of silicates: A cluster model able to reproduce the effect of "SiO4" polymerization on Raman intensities, J. Non-Crystall. Solids 370 (2013) $10-17$.

70. Ph. Colomban, R. de Laveaucoupet, V. Milande, On-site Raman spectroscopic analysis of Kutahya fritwares , J. Raman Spectrosc. 36[9] (2005) 857-863.

71. M. Pereira, T. de Lacerda-Aroso, M.J.M. Gomes, A. Mata, L.C. Alves, Ph. Colomban, , Ancient Portuguese Ceramic Wall Tiles (« Ajulejos »): Characterization of the Glaze and Ceramic Pigments, J. Nano Research 8 (2009) 79-88.

72. Ph. Coloban, Personal Communication.

73. T. Pradell, G. Molina, J. Molera, J. Pla, A. Labrador, The use of micro-XRD for the study of glaze color decorations, Appl. Phys. A 111[1] (2013) 121-127.

74. C. Viti, I. Borgia, B. Brunetti, A. Sgamellotti, M. Mellini, Microtexture and microchernistry of glaze and pigments in Italian Renaissance pottery from Gubbio and Deruta, J. Cult. Herit. 4[3] (2003) 199-210.

75. J. Pérez-Arantegui, M. Resano, E. Garcia-Ruiz, F. Vanhaecke, C. Roldan, J. Ferrero, J. Coll., Characterization of cobalt pigments found in traditional Valencian ceramics by means of laser ablation-inductively coupled plasma mass spectrometry and portable X-ray fluorescence spectrometry, Talanta 74[5] (2008) 1271-1280. 
76. J. Pérez-Arantegui, B. Montull, M. Resano, J.M. Ortega, Materials and technological evolution of ancient cobalt-blue-decorated ceramics: Pigments and work patterns in tinglazed objects from Aragon (Spain) from the 15th to the 18th century AD, J. Eur. Ceram. Soc. 29[12] (2009) 2499-2509. 


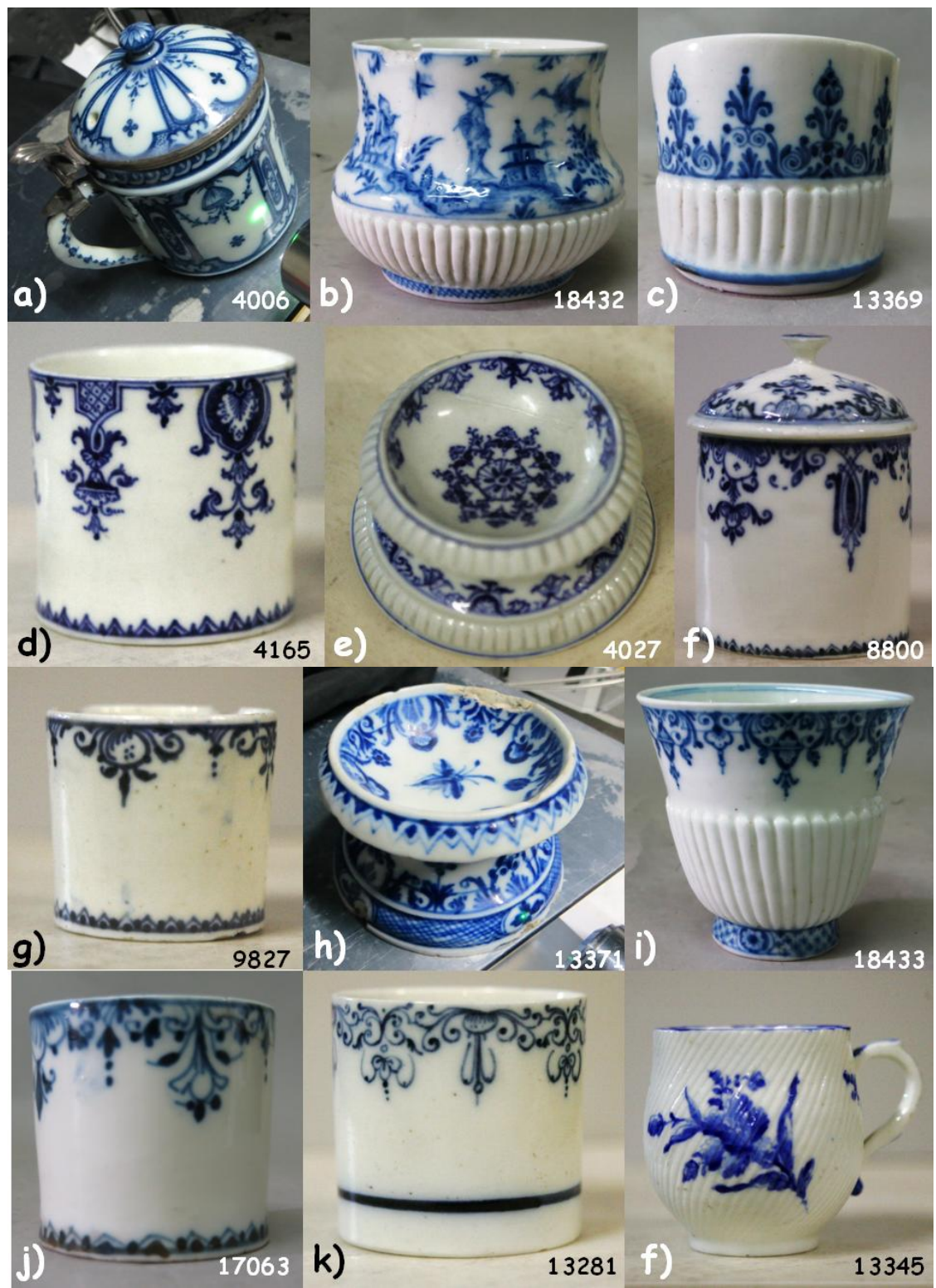

Fig. 1: Selection of blue-and-white soft-paste porcelains from the Collection of the Musée national de la Céramique (Cité de la Céramique, Sèvres \& Limoges): a) mustard or ointment pot assigned to Louis Poterat workshop (Rouen, circa 1680, MNC4006); b) ointment pot from Rouen Factory (end of $17^{\text {th }}$ century, MNC18432); c) ointment pot, Rouen or Paris Factory (end of the $17^{\text {th }}$-beginning of $18^{\text {th }}$ century, MNC13369); d) ointment pot from Saint-Cloud Factory (1695-1700, MNC4165); e) salt container from Saint-Cloud Factory (1691-1702, MNC4027); f) ointment pot from Saint-Cloud Factory (1715-1720, MNC8800); g) ointment pot assigned to Edouard Hébert Factory, Paris (circa 1710, MNC9827); h) salt container assigned to Dominique ou Pierre Chicaneau or Marie Moreau Saint-Cloud or Paris Factory (beginning of $18^{\text {th }}$ century, MNC13371); i) cup, Antoine Pavie Factory (1710-1720, MNC18433); j) ointment pot, Lille Factory (early $18^{\text {th }}$ century, MNC17063): k) ointment pot from Mennecy-Villiers Factory (after 1734; MNC13281); f) coffee cup from Edouard Hébert Factory, Paris (middle $18^{\text {th }}$ century, MNC13345). 


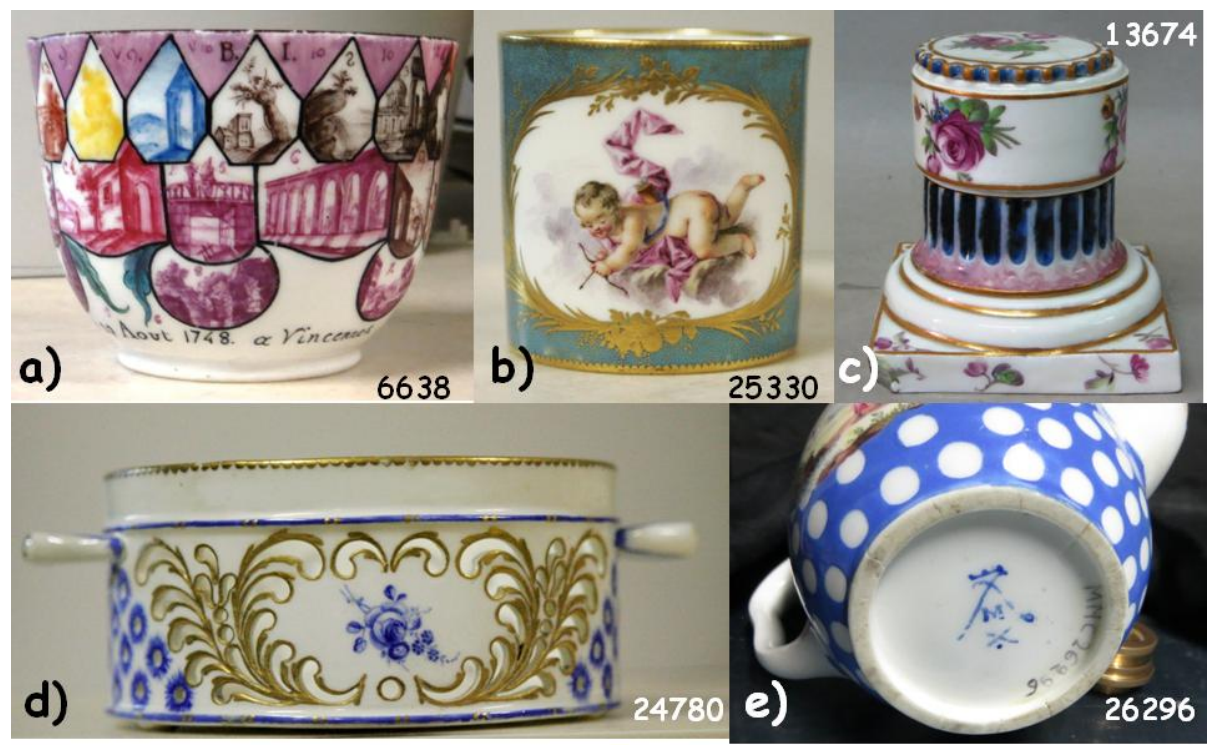

Fig. 2: Selection of artefacts with multi-colour decor from the Musée national de Céramique: a) Soft-paste porcelain pallet cup from Vincennes Royal Factory made by Pierre-Antoine-Henry Taunay (1748, MNC6639); soft-paste porcelain coffee cup from Vincennes Royal Factory (mark A: 1753, MNC25330); c) hard-paste porcelain salt container from Strasbourg Factory (midlle of $18^{\text {th }}$ century, MNC13674); d) softpaste porcelain ice cream cup from Vincennes Royal Factory (1764, MNC24780); e) soft-paste porcelain tea pot from Vincennes Royal Factory (middle of $18^{\text {th }}$ century, MNC26296). 


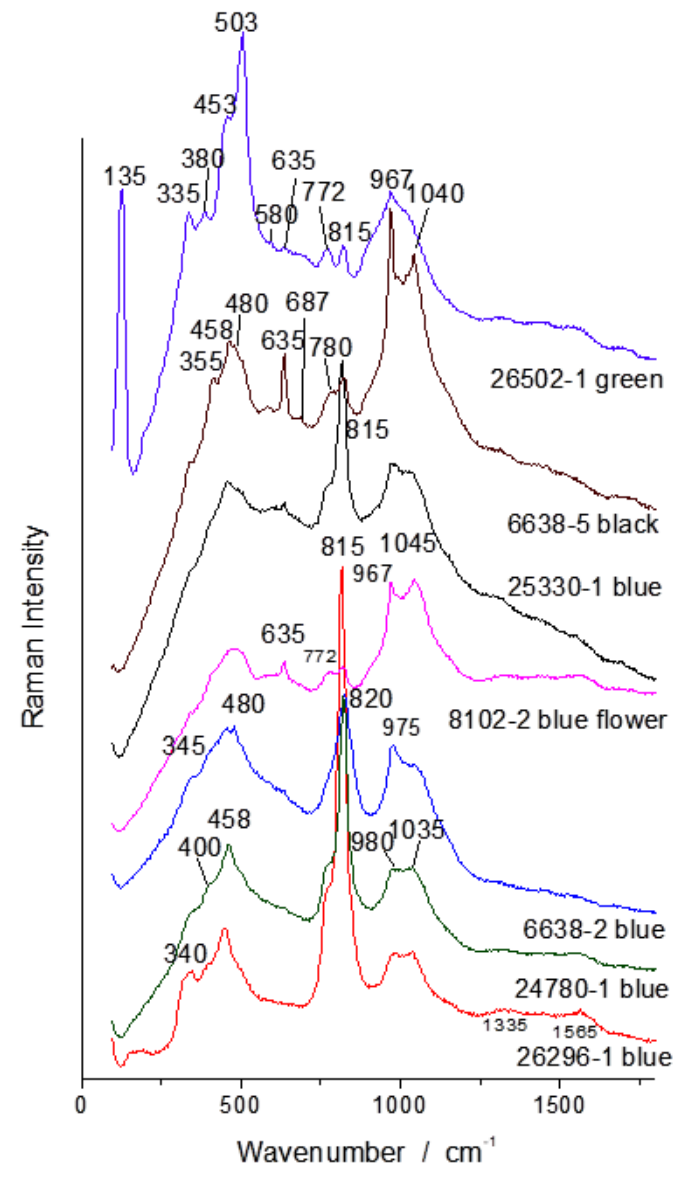

Fig. 3: Raman spectra collected on blue, green and black areas. See Table 1 and Supplementary Materials for information about the artefacts. 

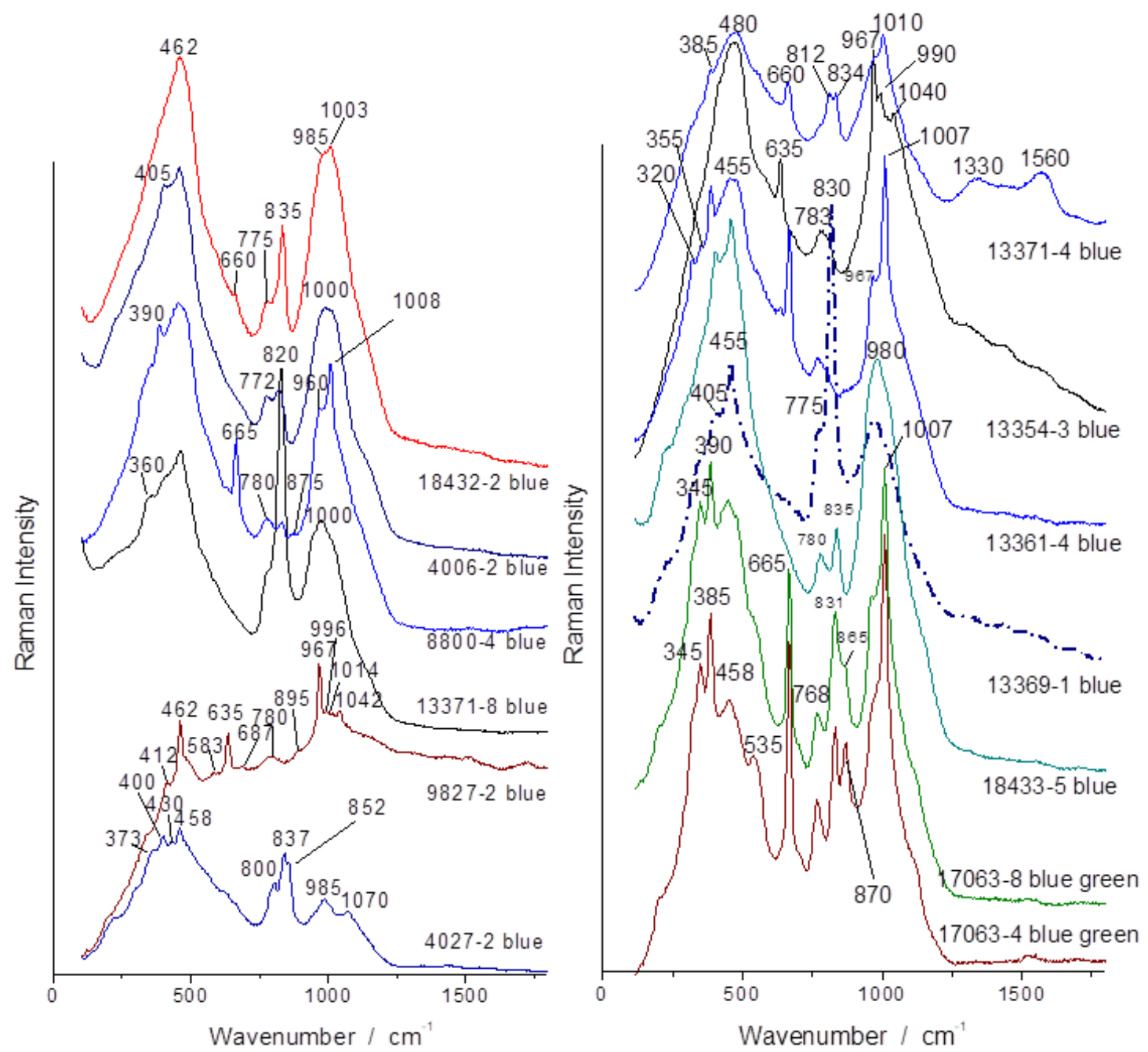

Fig. 4: Raman spectra collected on blue and blue- green areas. See table 1 and Supplementary Materials for details. 

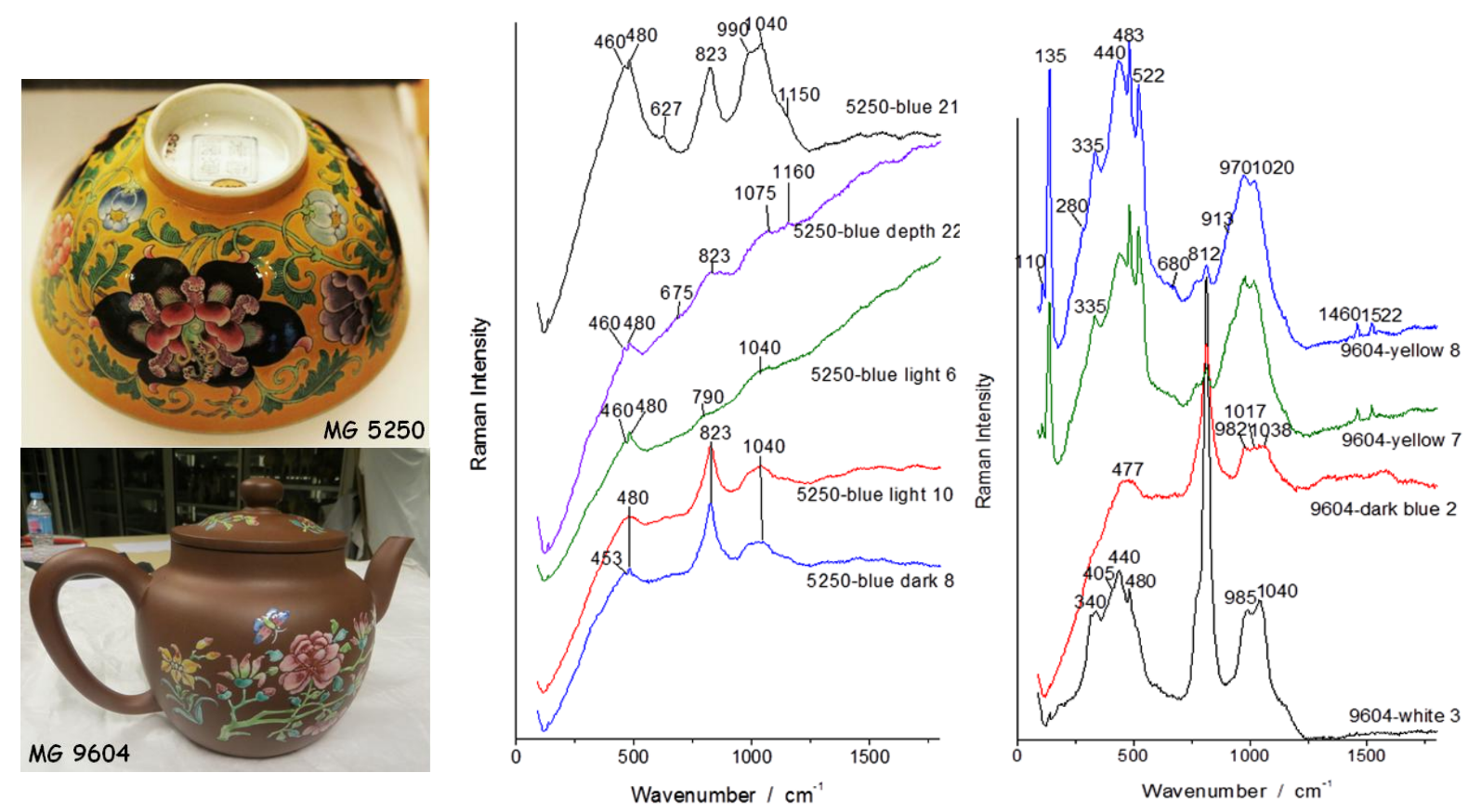

Fig. 5: Qing porcelain (MG5250, huafalang bowl, Kangxi yu zhi mark, ca. 1715-1722, imperial workshop) and stoneware (MG9604, Yixing Factory, $2^{\text {nd }}$ half of $18^{\text {th }}$ century) and representative Raman spectra recored on colored areas (see ref [] for details). 